\title{
COMPARISON OF CARDIAC OUTPUT DETERMINED BY THE BALLISTOCARDIOGRAPH (NICKERSON APPARATUS) AND BY THE DIRECT FICK METHOD ${ }^{1}$
}

\author{
BY RICHARD T. CATHCART, WILLIAM W. FIELD, AND \\ DICKINSON W. RICHARDS, JR.

\begin{abstract}
(From the Department of Medicine, Columbia University College of Physicians and Surgeons; and the Cardiopulmonary Laboratory of the First Medical Division and the Chest Service, Bellevue Hospital, New York, N. Y.)
\end{abstract}

(Submitted for publication March 19, 1952; accepted October 1, 1952)

\section{INTRODUCTION}

This paper presents a comparison of cardiac output measured by the direct Fick method, with that calculated from the Nickerson-Curtis form of ballistocardiograph (1), and is thus primarily a study of the latter method.

In the form of an apparatus first developed in this country by Starr and his colleagues (2), the ballistocardiograph was designed to measure cardiac output. In normal resting subjects a reasonably satisfactory agreement with cardiac output measured by other techniques was obtained $(3,4)$. However, the validity of the ballistic record as a measure of cardiac output has been questioned on theoretical grounds (5). When applied experimentally to abnormal circulatory states, moreover, considerable and sometimes wide discrepancies with values obtained by the direct Fick method were found. In traumatic shock, with rapid pulse rates, Cournand and his associates (6) encountered instances in which the ballistic record indicated a markedly increased cardiac output, whereas by the more reliable direct Fick procedure, the actual cardiac output was equally markedly decreased below normal. It was as if the systolic movement of the rapidly beating but relatively empty heart in the presence of a marked reduction of the systemic peripheral resistance produced a ballistic impulse closely simulating that resulting from a large blood ejection.

Extensive further studies, especially by Starr and his colleagues, have led them to the conclusion that the relation between the ballistic record and cardiac output is "a distant one," and that the

1 This investigation was supported by a research grant (H-103) from the National Heart Institute, of the $\mathrm{Na}$ tional Institutes of Health, Public Health Service. ballistocardiogram is actually a measure of force rather than of systolic output (7). In spite of the above, the ballistocardiogram continues to be used to measure cardiac output; though sometimes only as an indication of "relative" change from one physiological state to another, in the same individual (8-10). It is thus of some importance to attempt to resolve the question whether such use of this instrument is valid, or not.

In 1944, Nickerson and Curtis reported the design of a critically damped, low frequency ballistocardiograph, in which the natural or periodic oscillation of the Starr apparatus was largely eliminated. Nickerson, Warren, and Brannon (11) later published the results of some measurements comparing cardiac output calculated from this ballistocardiograph with those obtained nearly simultaneously by the direct Fick method. From the first 50 observations in subjects without heart disease, empirical constants were derived for use in the computation of cardiac output. Using these, it was found that 87 per cent of 54 patients with various non-cardiac conditions, had cardiac outputs within 25 per cent of the values obtained with the catheter technique ("direct Fick"). Of 17 patients with heart disease (excluding aortic insufficiency) the ballistic cardiac output was within 25 per cent of the direct Fick in only 60 per cent, but outside this range in 40 per cent of determinations. This rather wide scatter may be compared with the accuracy of the direct Fick method itself, which will be discussed in detail below.

It should be noted that the Warren-Nickerson technique involved voluntary breath-holding during the recording of the ballistocardiogram.

More recently, the Nickerson ballistocardiograph has been used in various studies, but no 
further inquiry has been made of its validity as a method of measuring cardiac output.

As indicated above, the purpose of the present investigation is to analyze further the use of the Nickerson ballistocardiograph as a means of measuring cardiac output, comparing values so obtained, in a considerable variety of clinical material, with those obtained, as nearly simultaneously as possible, by the direct Fick method using cardiac or pulmonary artery catheterization. The experimental work will be presented in three parts : 1) a study of the effects of breath-holding or voluntary apnea, on the ballistic record; 2) comparative measurements of ballistocardiograph cardiac output with direct Fick cardiac output in the basal resting state; and finally, 3) a report of a few experiments which were attempted, to compare ballistic and direct Fick determinations when cardiac output was altered in the same subject, by means of an epinephrine infusion.

PART I

\section{Effects of Respiration and Respiratory Chest Position on the Ballistocardiogram}

\section{a. Apparatus}

The ballistocardiograph was constructed according to the design of Nickerson and varied from it in no essential detail. It had a natural undamped frequency of 1.5 per second. As the weight of the patient varied the spring length was altered in order to maintain the same period. Critical damping was obtained before each study by placing sandbags equivalent to the patient's weight upon the apparatus and adjusting the oil damping system.

\section{b. Methods}

Ninety-two subjects were studied in all. About 25 per cent of these were normal trained medical students and interns; the remainder were patients selected from the general ward population covering all adult age groups and numerous clinical diagnoses. Not all of the subjects were in a basal state, but all lay on the ballistocardiograph for a varying period, usually about 30 minutes, until the blood pressure and the pulse rate had become stable. Several records were taken on each subject during quiet respiration and voluntary apnea. The breath was held in midposition.

A number of records were also taken on trained normal subjects during quiet breathing and with the breath held in various phases of the respiratory cycle and consequently a varying volume of air in the lungs and varying point of fixation of the diaphragm. The subjects breathed into a spirometer simultaneously with the recording of the ballistocardiogram. In this manner the exact position in which the breath was held and the actual volume of air in the lungs at the time of the output measurement could be graphically recorded.

Cardiac output determinations were calculated from the Nickerson formula,

$$
\mathrm{SV}=5.02 \frac{\mathrm{F} \times \mathrm{P}}{\mathrm{T} \times \mathrm{L}}(1),
$$

where: $\mathrm{SV}=$ stroke volume in cubic centimeters

5.02 = the empirical constant determined by Nickerson to provide the best fit between the ballistic results and the direct Fick data

$F=$ the force required to displace the apparatus the distance between the peak of the first major footward deflection (I) and the first major headward deflection ( $\mathrm{J}$ ). (This is derived from a simple ratio using a 50-gram weight to calibrate the bed.)

$\mathrm{P}=$ the square root of one-half of the sum of the systolic and diastolic blood pressures

$\mathrm{T}=$ the time, in seconds, from the peak of the I-wave to the peak of the J-wave

$\mathrm{L}=$ the length of the patient in centimeters.

\section{c. Results}

The general average of ballistocardiographic cardiac output determinations during quiet breathing was 5.28 liters per minute as compared with 5.57 liters per minute with the breath held in midposition. The difference of 0.29 liters per minute or 6 per cent is not significant. However, a marked variation was observed between individual records.

Figure 1 is a frequency distribution curve showing that only 43 of the 92 cases (or 47 per cent) fall into the range of \pm 10 per cent of exact agreement; only 62 (or 67 per cent) fall into the range

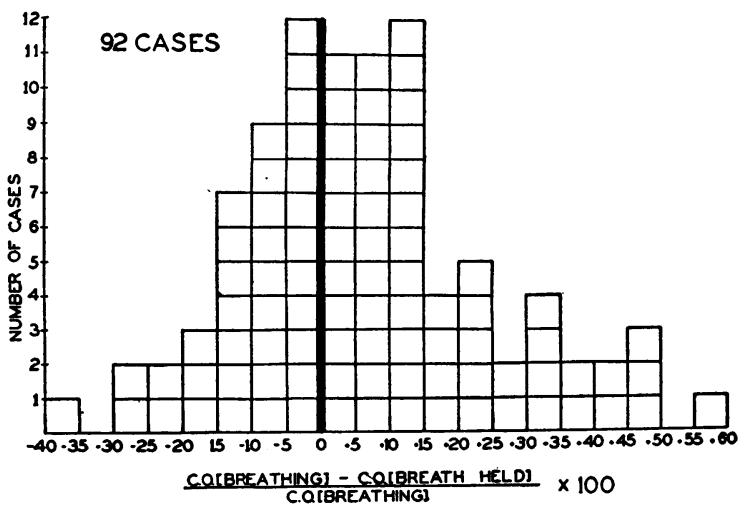

Fig. 1. Effects of Breath-Holding vs. Quiet Respiration on Cardiac Output as Calculated from the BALLISTOCARDIOGRAM 
of \pm 15 per cent. In the remainder, 33 per cent of the total, the variation exceeded 15 per cent, with an overall range of -40 per cent to +60 per cent.

Figure 2 is a diagrammatic representation of the results obtained when a trained subject breathed into a spirometer, simultaneously with the recording of the ballistocardiogram. This diagram was compiled from the data of one individual, but variation of a similar degree was observed in all of the patients studied. It is seen that in the case illustrated, with a fairly constant heart

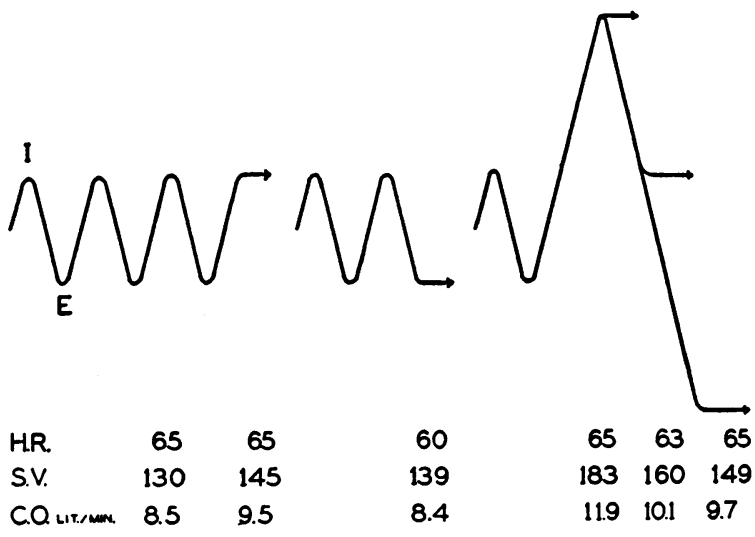

Fig. 2. EFfects of Respiratory Position of the Chest on Cardiac Output, as Calculated From the Ballistocardiogram, in One Normal Subject

Curve gives a schematic representation of the chest position at the time each ballistocardiogram was taken, with the figures (indicated below) of the corresponding cardiac output volumes. $H R=$ heart rate per minute. $\mathrm{SV}=$ stroke volume in cc. C.O. = cardiac output in liters per minute. From left to right the figures represent: 1) quiet breathing, 2) end of normal inspiration, 3) end of normal expiration, 4) deep inspiration, 5) mid-position after deep inspiration, 6) deep expiration.

rate, both the stroke volume and the cardiac output varied by as much as 40 per cent, according to the position in which the breath was held. In this particular case the lowest values for cardiac output were found with the breath held following a normal expiration, the highest at the point of maximal inspiration. In six other patients similarly studied, there was a comparable degree of variation in the cardiac output values obtained with the breath held in different positions. However, the maximum value was not constantly found at the height of inspiration.

\section{d. Comments}

It has long been known that any change from normal resting respiration will upset the steady state of the circulation. The experiments above described are few, but indicate that voluntary breath-holding causes somewhat unpredictable but at times large changes in the ballistic record. This problem has also been studied by Starr and Friedland (12). Although the general average of the calculated cardiac outputs while breathing is the same as the average calculated from records obtained during apnea, this finding is not of primary interest, since it is the validity of the individual cardiac output measurement that we are concerned with here. When the position of apnea was recorded and the actual volume of air in the lungs measured, the influence on the cardiac output as recorded by the ballistocardiograph appeared to depend upon the volume of air in the lungs and the position of the diaphragm. In individual cases the cardiac output as measured by the ballistocardiograph was found to vary by more than 3 liters dependent entirely upon the actual position in which the breath was held. These findings would tend to indicate that the ballistic records taken during voluntary apnea are unreliable and offer no standard basis upon which cardiac output determinations may be compared.

Since records taken with the breath held seemed unreliable, our attention became focused upon those taken during quiet breathing. Here also considerable difficulty was encountered. The natural period of the bed is low and of such a nature that the type of respiration often interferes with the recording of a readable ballistic pattern. In general, the more rapid and vigorous the respiratory effort, the greater the degree of interference and therefore the more limited the use of the low frequency ballistocardiograph. In order to obtain a satisfactory record during breathing, a moderate degree of cooperation of the subject is required, in keeping the respirations quiet and even. This was found to be no problem in young normal subjects, but with the general ward population at Bellevue Hospital nearly 40 per cent of the patients were found to be unsatisfactory subjects. Patients with pulmonary disease and patients in congestive heart failure comprise a group where dyspnea is frequently marked. In 
TABLE I

Comparison of cardiac output by direct Fick method (cardiac catheterization) and by Nickerson ballistocardiograph

\begin{tabular}{|c|c|c|c|c|c|c|c|c|c|c|c|c|}
\hline Subject & Sex & Age & Height & Weight & $\begin{array}{l}\mathrm{O}_{2} \\
\text { Cons. }\end{array}$ & $\underset{\text { diff. }}{\mathrm{A}-\mathrm{O}}$ & $\begin{array}{l}\text { Cardiac } \\
\text { outupt } \\
\text { Fick }\end{array}$ & $\begin{array}{l}\text { Prest } \\
\text { Po }\end{array}$ & $\begin{array}{l}\text { res } \\
\text { Pd }\end{array}$ & $\begin{array}{l}\text { Heart } \\
\text { rate }\end{array}$ & $\begin{array}{c}\text { Cardiac } \\
\text { output } \\
\text { Ballisto- } \\
\text { cardiograph }\end{array}$ & Diagnosis \\
\hline & & yrs. & in. & lbs. & $\begin{array}{c}c c . / \\
\min .\end{array}$ & $\begin{array}{c}c c .1 \\
100 \\
c c .\end{array}$ & $l . / \mathrm{min}$. & \multicolumn{2}{|c|}{ mm.Hg. } & \multirow{8}{*}{$\begin{array}{l}\mathbf{6 2} \\
77 \\
60 \\
\mathbf{5 8} \\
\mathbf{5 7} \\
\mathbf{6 2} \\
\mathbf{6 2} \\
\mathbf{6 1} \\
\mathbf{7 9}\end{array}$} & $l . / \min$. & \\
\hline A. C. & $\mathbf{F}$ & 33 & $60 \frac{1}{2}$ & 103 & 157 & 2.9 & 5.42 & 96 & 58 & & 2.53 & Oxyuriasis \\
\hline & $\mathbf{M}$ & 62 & 68 & 130 & 182 & 5.0 & 3.64 & 126 & 72 & & 4.10 & Ca. of cardia \\
\hline $\begin{array}{l}\text { P. D. } \\
\text { J. N. (1) }\end{array}$ & $\begin{array}{l}\mathbf{M} \\
\mathbf{M}\end{array}$ & $\begin{array}{l}61 \\
42\end{array}$ & $\begin{array}{l}69 \\
68 \frac{1}{2}\end{array}$ & $\begin{array}{l}134 \\
152\end{array}$ & $\begin{array}{l}237 \\
254\end{array}$ & $\begin{array}{l}4.4 \\
3.8\end{array}$ & $\begin{array}{l}5.39 \\
6.68\end{array}$ & $\begin{array}{l}122 \\
108\end{array}$ & $\begin{array}{l}68 \\
70\end{array}$ & & $\begin{array}{l}2.45 \\
4.35\end{array}$ & $\begin{array}{l}\text { Pulmonary Tbc., IIB } \\
\text { Bronchiectasis }\end{array}$ \\
\hline (2) & & & & & 253 & 3.7 & 6.84 & 112 & 70 & & 3.15 & \\
\hline W.P. (1) & $\mathbf{M}$ & 39 & 72 & 163 & 253 & 3.1 & $\begin{array}{l}8.16 \\
706\end{array}$ & 102 & 70 & & $\begin{array}{l}4.30 \\
4.09\end{array}$ & Nephritis \\
\hline H.W. & $\mathbf{M}$ & 39 & 67 & 133 & 229 & 4.7 & 4.87 & 130 & 95 & & 4.30 & Gastroenteritis \\
\hline J. M. (1) & $\mathbf{M}$ & 56 & $68 \frac{1}{2}$ & 125 & $\begin{array}{l}254 \\
239\end{array}$ & $\begin{array}{l}2.9 \\
3.0\end{array}$ & $\begin{array}{l}8.76 \\
7.97\end{array}$ & $\begin{array}{l}128 \\
135\end{array}$ & $\begin{array}{l}78 \\
80\end{array}$ & & $\begin{array}{l}4.80 \\
5.20\end{array}$ & $\begin{array}{l}\text { Tbc. and pernicious } \\
\text { anemia }\end{array}$ \\
\hline C. L. (1) & $\mathbf{M}$ & 50 & $69 \frac{1}{2}$ & 139 & 254 & 3.6 & 7.06 & 110 & 70 & 57 & 3.30 & Chronic alcoholism \\
\hline N. G. (1) & $\mathbf{M}$ & 35 & 69 & 164 & $\begin{array}{l}224 \\
207\end{array}$ & $\begin{array}{l}3.3 \\
3.2\end{array}$ & $\begin{array}{l}6.79 \\
6.46\end{array}$ & $\begin{array}{l}112 \\
112\end{array}$ & $\begin{array}{l}72 \\
72\end{array}$ & $\begin{array}{l}56 \\
60\end{array}$ & $\begin{array}{l}2.85 \\
4.80\end{array}$ & Peptic ulcer \\
\hline (2) & & & & & 213 & 3.0 & 7.10 & 116 & 73 & 66 & 5.30 & \\
\hline $\begin{array}{ll}\text { J.P. (1) } \\
\text { (2) }\end{array}$ & $\mathbf{M}$ & 52 & $69 \frac{1}{2}$ & 136 & $\begin{array}{l}232 \\
215\end{array}$ & $\begin{array}{l}4.0 \\
3.1\end{array}$ & $\begin{array}{l}5.80 \\
6.62\end{array}$ & $\begin{array}{l}125 \\
130\end{array}$ & $\begin{array}{l}85 \\
80\end{array}$ & $\begin{array}{l}78 \\
71\end{array}$ & $\begin{array}{l}4.90 \\
4.70\end{array}$ & Tbc. \\
\hline R.R. (1) & $\mathbf{M}$ & 45 & $63 \frac{1}{2}$ & 133 & 255 & $\begin{array}{l}4.8 \\
4.5\end{array}$ & 5.32 & 125 & 85 & 66 & 4.15 & Alcoholism \\
\hline W. G. (1) & $\mathbf{M}$ & 54 & 621 & 119 & 307 & 4.2 & 5.60 & 120 & 88 & 80 & 3.90 & Diverticulosis \\
\hline D. B. & $\mathbf{M}$ & 45 & 66 & 148 & $\begin{array}{l}301 \\
248\end{array}$ & $\begin{array}{l}4.4 \\
2.8\end{array}$ & $\begin{array}{l}5.20 \\
8.86\end{array}$ & $\begin{array}{l}130 \\
104\end{array}$ & $\begin{array}{l}90 \\
83\end{array}$ & $\begin{array}{l}80 \\
74\end{array}$ & $\begin{array}{l}3.20 \\
4.55\end{array}$ & Pneumonia \\
\hline R. N. (1) & $\mathbf{M}$ & 50 & $65 \frac{1}{2}$ & 115 & $\begin{array}{l}178 \\
183\end{array}$ & $\begin{array}{l}3.8 \\
3.1\end{array}$ & $\begin{array}{l}4.69 \\
5.90\end{array}$ & $\begin{array}{l}116 \\
116\end{array}$ & $\begin{array}{l}74 \\
74\end{array}$ & $\begin{array}{l}74 \\
70\end{array}$ & $\begin{array}{l}4.88 \\
5.04\end{array}$ & Pneumonia \\
\hline C. B. (1) & $\mathbf{M}$ & 53 & 66 & 135 & 237 & 3.9 & 6.09 & 98 & 70 & 68 & 3.97 & Bronchiectasis \\
\hline S. G. $\stackrel{(2)}{(1)}$ & $\mathbf{M}$ & 48 & 68 & 143 & $\begin{array}{l}220 \\
295\end{array}$ & $\begin{array}{l}3.6 \\
3.2\end{array}$ & $\begin{array}{l}6.12 \\
9.22\end{array}$ & $\begin{array}{l}105 \\
130\end{array}$ & $\begin{array}{l}75 \\
88\end{array}$ & $\begin{array}{r}64 \\
112\end{array}$ & $\begin{array}{l}4.40 \\
7.73\end{array}$ & Atypical pneumonia \\
\hline (2) & & & & & 287 & 3.1 & 9.25 & 137 & 88 & 110 & 8.20 & \\
\hline A. A. (1) & $\mathbf{M}$ & 46 & $67 \frac{1}{2}$ & 134 & $\begin{array}{l}261 \\
260\end{array}$ & $\begin{array}{l}3.0 \\
3.6\end{array}$ & $\begin{array}{l}8.70 \\
7.22\end{array}$ & $\begin{array}{l}122 \\
128\end{array}$ & $\begin{array}{l}78 \\
78\end{array}$ & $\begin{array}{l}72 \\
68\end{array}$ & $\begin{array}{l}4.68 \\
3.76\end{array}$ & Infectious hepatitis \\
\hline E. H. & $\mathbf{M}$ & 54 & $66 \frac{1}{2}$ & 130 & 225 & 3.1 & 7.25 & 102 & 68 & 80 & 4.47 & Pneumonia \\
\hline J. N. (1) & $\mathbf{M}$ & 62 & 73 & 174 & $\begin{array}{l}222 \\
226\end{array}$ & $\begin{array}{l}5.0 \\
5.3\end{array}$ & $\begin{array}{l}4.44 \\
4.24\end{array}$ & $\begin{array}{l}160 \\
160\end{array}$ & $\begin{array}{l}105 \\
108\end{array}$ & $\begin{array}{l}66 \\
65\end{array}$ & $\begin{array}{l}3.80 \\
3.55\end{array}$ & $\begin{array}{l}\text { Hypertensive cardio- } \\
\text { vascular disease }\end{array}$ \\
\hline T. M. (1) & $\mathbf{M}$ & 37 & 66 & 158 & 248 & 3.4 & 7.29 & 108 & 70 & 68 & 3.95 & Peptic ulcer \\
\hline B. P. & $\mathbf{M}$ & 41 & $63 \frac{1}{2}$ & 156 & 254 & 3.9 & 6.52 & 240 & 165 & 97 & $\begin{array}{l}4.10 \\
5.48\end{array}$ & Hypertensive cardio- \\
\hline C. G. (1) & $\mathbf{M}$ & 59 & $68 \frac{1}{2}$ & $140 \frac{1}{2}$ & 202 & 3.7 & 5.46 & 110 & 76 & 61 & 2.04 & Nephritis \\
\hline F.S. (1) & $\mathbf{M}$ & 27 & $69 \frac{1}{3}$ & 142 & $\begin{array}{l}207 \\
253\end{array}$ & $\begin{array}{l}3.7 \\
3.4\end{array}$ & $\begin{array}{l}5.59 \\
7.44\end{array}$ & $\begin{array}{l}110 \\
110\end{array}$ & $\begin{array}{l}75 \\
68\end{array}$ & $\begin{array}{l}61 \\
60\end{array}$ & $\begin{array}{l}2.01 \\
3.57\end{array}$ & Pneumonia \\
\hline & & & & & 236 & 3.4 & 6.94 & 112 & 62 & 59 & 3.79 & \\
\hline & M & 46 & 67 & 130 & 192 & 4.1 & 4.68 & 92 & 64 & 70 & 4.10 & Pneumonia \\
\hline $\begin{array}{l}\text { J. B. (1) } \\
\text { (2) }\end{array}$ & $\mathbf{M}$ & 60 & 65 & 110 & $\begin{array}{l}188 \\
183\end{array}$ & $\begin{array}{l}3.8 \\
3.3\end{array}$ & $\begin{array}{l}4.95 \\
5.54\end{array}$ & $\begin{array}{l}100 \\
100\end{array}$ & $\begin{array}{l}72 \\
72\end{array}$ & $\begin{array}{l}80 \\
80\end{array}$ & $\begin{array}{l}6.70 \\
6.34\end{array}$ & \\
\hline $\begin{array}{l}\text { C. D. } \\
\text { T. W. }\end{array}$ & $\begin{array}{l}\mathbf{M} \\
\mathbf{M}\end{array}$ & $\begin{array}{l}31 \\
41\end{array}$ & $\begin{array}{l}68 \frac{1}{2} \\
68\end{array}$ & $\begin{array}{l}176 \\
134\end{array}$ & $\begin{array}{l}269 \\
225\end{array}$ & $\begin{array}{l}3.5 \\
3.5\end{array}$ & $\begin{array}{l}7.68 \\
6.43\end{array}$ & $\begin{array}{l}110 \\
126\end{array}$ & $\begin{array}{l}78 \\
78\end{array}$ & $\begin{array}{l}63 \\
81\end{array}$ & $\begin{array}{l}5.60 \\
5.15\end{array}$ & $\begin{array}{l}\text { Nasopharyngitis } \\
\text { Lymphogranuloma } \\
\text { venereum }\end{array}$ \\
\hline B. P. (1) & $\mathbf{M}$ & 41 & $63 \frac{1}{2}$ & 156 & 247 & 3.8 & 6.50 & 190 & 110 & 92 & 6.50 & Hypertensive cardio- \\
\hline C. $M^{(2)}$ & $\mathbf{M}$ & 40 & 64 & 128 & $\begin{array}{l}238 \\
236\end{array}$ & $\begin{array}{l}3.8 \\
4.0\end{array}$ & $\begin{array}{l}0.27 \\
5.90\end{array}$ & $\begin{array}{l}190 \\
125\end{array}$ & $\begin{array}{r}110 \\
70\end{array}$ & 76 & $\begin{array}{l}0.22 \\
5.10\end{array}$ & $\begin{array}{l}\text { vascular disease } \\
\text { Peptic ulcer }\end{array}$ \\
\hline C. R. (1) & $\mathbf{M}$ & 49 & $69 \frac{1}{2}$ & 123 & $\begin{array}{l}191 \\
214\end{array}$ & $\begin{array}{l}4.4 \\
4.8\end{array}$ & $\begin{array}{l}4.34 \\
4.46\end{array}$ & $\begin{array}{l}190 \\
190\end{array}$ & $\begin{array}{l}110 \\
110\end{array}$ & $\begin{array}{l}72 \\
70\end{array}$ & $\begin{array}{l}4.50 \\
4.08\end{array}$ & $\begin{array}{l}\text { Hypertensive cardio- } \\
\text { vascular disease }\end{array}$ \\
\hline C. R. & $\mathbf{M}$ & 49 & $69 \frac{1}{2}$ & 123 & 22 & & & 220 & 12 & & & $\begin{array}{l}\text { Hypertensive cardio- } \\
\text { vascular disease }\end{array}$ \\
\hline $\begin{array}{l}\text { A. Y. } \\
\text { M. W. }\end{array}$ & $\mathbf{M}$ & $\begin{array}{l}37 \\
40\end{array}$ & 64 & $\begin{array}{l}96 \frac{1}{2} \\
142\end{array}$ & $\begin{array}{l}246 \\
245\end{array}$ & $\begin{array}{l}3.4 \\
4.2\end{array}$ & $\begin{array}{l}7.24 \\
5.84\end{array}$ & $\begin{array}{l}120 \\
180\end{array}$ & $\begin{array}{l}75 \\
90\end{array}$ & $\begin{array}{l}88 \\
86\end{array}$ & $\begin{array}{l}6.60 \\
4.95\end{array}$ & $\begin{array}{l}\text { Cor pulmonale } \\
\text { Hypertensive cardio- } \\
\text { vascular disease }\end{array}$ \\
\hline J. O. (1) & $\mathbf{M}$ & 22 & 70 & 132 & 220 & 4.4 & 5.00 & 108 & 70 & 72 & 5.30 & La grippe \\
\hline W. H. & $\mathbf{M}$ & 50 & 68 & 153 & $\begin{array}{l}220 \\
236\end{array}$ & $\begin{array}{l}4.5 \\
5.0\end{array}$ & $\begin{array}{l}5.02 \\
4.72\end{array}$ & 220 & 125 & 60 & $\begin{array}{l}4.00 \\
4.10\end{array}$ & $\begin{array}{l}\text { Hypertensive cardio- } \\
\text { vascular disease }\end{array}$ \\
\hline C. A. (1) & $\mathbf{M}$ & 22 & $64 \frac{1}{2}$ & 122 & 247 & 4.1 & 6.03 & 115 & $\begin{array}{l}80 \\
80\end{array}$ & $\begin{array}{l}91 \\
85\end{array}$ & $\begin{array}{l}7.40 \\
7.30\end{array}$ & Pulmonary Tbc., minimal \\
\hline J. H. (1) & $\mathbf{M}$ & 21 & 75 & 190 & 322 & 3.5 & 9.20 & 124 & $\begin{array}{l}80 \\
80\end{array}$ & 65 & 7.90 & Hepatitis \\
\hline H. W. & $\mathbf{M}$ & 38 & 69 & 141 & 267 & $\begin{array}{l}3.9 \\
6.0\end{array}$ & $\begin{array}{l}8.11 \\
4.45\end{array}$ & $\begin{array}{l}120 \\
215\end{array}$ & $\begin{array}{r}80 \\
150\end{array}$ & $\begin{array}{l}03 \\
96\end{array}$ & $\begin{array}{l}0.82 \\
4.60\end{array}$ & $\begin{array}{l}\text { Hypertensive cardio- } \\
\text { vascular disease }\end{array}$ \\
\hline M. C. (1) & $\mathbf{M}$ & 45 & 68 & 141 & $\begin{array}{l}246 \\
220\end{array}$ & $\begin{array}{l}3.5 \\
3.6\end{array}$ & $\begin{array}{l}7.04 \\
6.12\end{array}$ & $\begin{array}{l}202 \\
210\end{array}$ & $\begin{array}{l}105 \\
105\end{array}$ & $\begin{array}{l}59 \\
56\end{array}$ & $\begin{array}{l}1.68 \\
1.88\end{array}$ & $\begin{array}{l}\text { Hypertensive cardio- } \\
\text { vascular disease }\end{array}$ \\
\hline
\end{tabular}


the presence of dyspnea it was usually impossible to secure a calculable ballistic record.

\section{PART II}

Comparison of Cardiac Output Determinations by the Ballistocardiographic and the Fick Methods

\section{a. Methods}

The subjects studied were selected from the general hospital population. They were chosen on the basis of cooperation, calculability of the ballistic record, and, except in two instances, the absence of valvular heart disease. All were in a basal state in the morning. These patients suffered from a variety of clinical conditions, as indicated in Table I. However, none were febrile and all of those suffering from an acute disease were far along in the convalescent state.

An intracardiac catheter was inserted into the right heart under direct fluoroscopic vision. In the earlier cases it was placed in the right auricle just in front of the tricuspid valve; in the majority of cases, however, in the main pulmonary artery. The subject was then transferred by means of a stretcher to the ballistocardiograph. After a period of stabilization, cardiac output measurements were made by both methods as nearly simultaneously as possible. For the Fick determinations, expired air was collected over a 2-minute period. Thirty seconds after the beginning of the collection of expired air, arterial and mixed venous blood samples were drawn slowly and simultaneously over a 1-minute period. Blood analyses were performed according to the method of Van Slyke, gas analyses according to Scholander. Duplicate determinations were made on each sample.

The ballistocardiograms used for comparison with the direct Fick values were taken during quiet breathing. Since the ballistic record varies from inspiration to expiration, the values from all heart beats through at least two respiratory cycles were calculated individually and then averaged, to give the cardiac output figure.

In all, 64 determinations were made on 40 individuals. All ballistocardiographic cardiac outputs were calculated from records taken during quiet breathing. Again all calculations were made according to the formula

$$
\mathrm{SV}=5.02 \frac{\mathrm{F} \times \mathrm{P}}{\mathrm{T} \times \mathrm{L}}
$$

as already described.

\section{b. Validity of the direct Fick method for measur- ing cardiac output}

The validity of the Fick method as a physiological measurement of cardiac output has recently been carefully studied by Seely, Nerlich, and Gregg (13). These authors, using anesthetized dogs, made serial determinations of car-

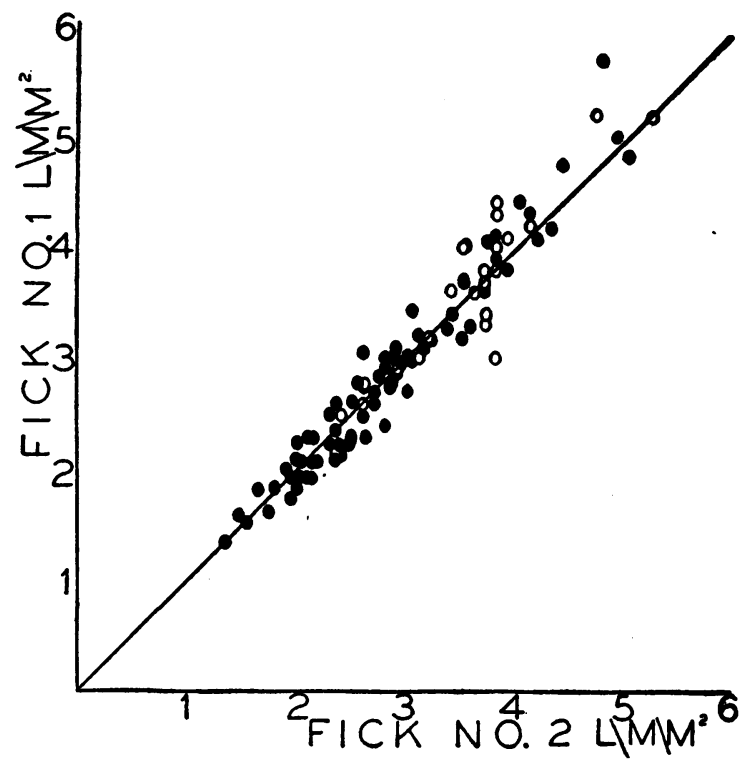

Fig. 3. Scatter Diagram of Cardic Indices as Measured by the Direct Fick Method on Two SucCessive Determinations

Open circles represent cases included in the present study.

diac output using both the Fick and the rotameter methods. The agreement was excellent. The average variation was \pm 5 per cent. When the amount of blood flow was experimentally increased by the infusion of whole blood or epinephrine, the close relationship between the two methods was maintained. The authors conclude that "when the Fick procedure was compared to a direct method of high accuracy, there was excellent agreement in a variety of hemodynamic states."

There remains the question of the accuracy of the Fick procedure in the hands of any individual investigator or laboratory. In an effort to evaluate the Fick method and to establish the degree to which it can be reduplicated, we have recently analyzed the data from the Cardioplumonary Laboratory of the Columbia University Division at Bellevue Hospital.

In all, 100 cases were found where successive Fick determinations had been made on the same individual under the same physiological conditions during the past four years. Of these 100 cases, 22 are included in the present study. The cases were taken consecutively and represent all subjects studied in this Laboratory where successive determinations were made at rest, under 
basal conditions, and during a steady state of respiration and circulation. These data were accumulated by three different catheterization teams. The subjects include all ranges of cardiac output levels with varied clinical conditions. There are many normal individuals and many with heart disease and far advanced congestive heart failure.

The variation of successive Fick determinations in these 100 cases was found to be 0 to 5 per cent in 52 cases, 6 to 10 per cent in 31 cases, and 11 to 15 per cent in 15 cases. There were only two instances where successive measurements differed by more than 15 per cent. Thus in 83 per cent of the cases studied, the variation was 10 per cent or less. The average variation was 6.6 per cent. The mean cardiac index in one series of duplicates was 2.97 liters per minute per square meter, as compared with a mean of 2.94 liters per minute per square meter in the other.
The average variation of the 22 cases included in the present study was identical to the above. The frequency distribution curve of these 22 was likewise similar to that of the entire group.

A statistical analysis of the data obtained from the successive determinations revealed that 1 ) there was a correlation coefficient of 0.975 , and 2) the standard deviation of a single cardiac index determination was 0.17 liters per minute per square meter of body surface.

It was further calculated from the standard deviation that any two independent observations on the same patient may with 95 per cent confidence vary one from the other by no more than 0.48 liters per minute per square meter. In about 70 per cent of the duplicates the difference will not exceed 0.24 liters per minute per square meter. The scatter of these results is plotted in Figure 3.

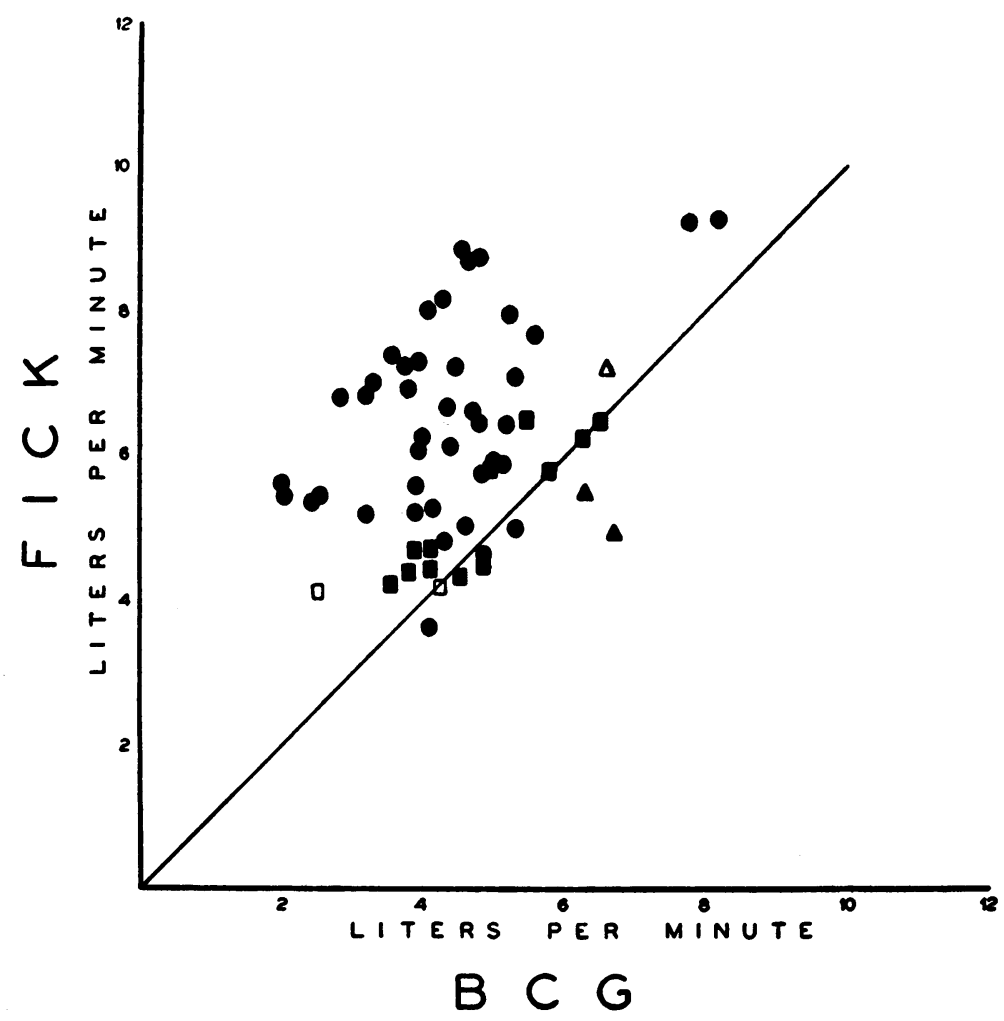

Fig. 4. Scatter Diagram of Cardiac Output Calculated from Ballistocardiogram, as Compared with Cardiac Output by the Direct Fick Method. Calculations According to Nickerson Formula

Solid circles $=$ patients with no heart disease. Solid squares $=$ hypertensive vascular disease. Open squares $=$ mitral stenosis. Triangles $=$ cor pulmonale. These cases, and a few additional cases as well, are presented also in Table $\mathrm{I}$. 


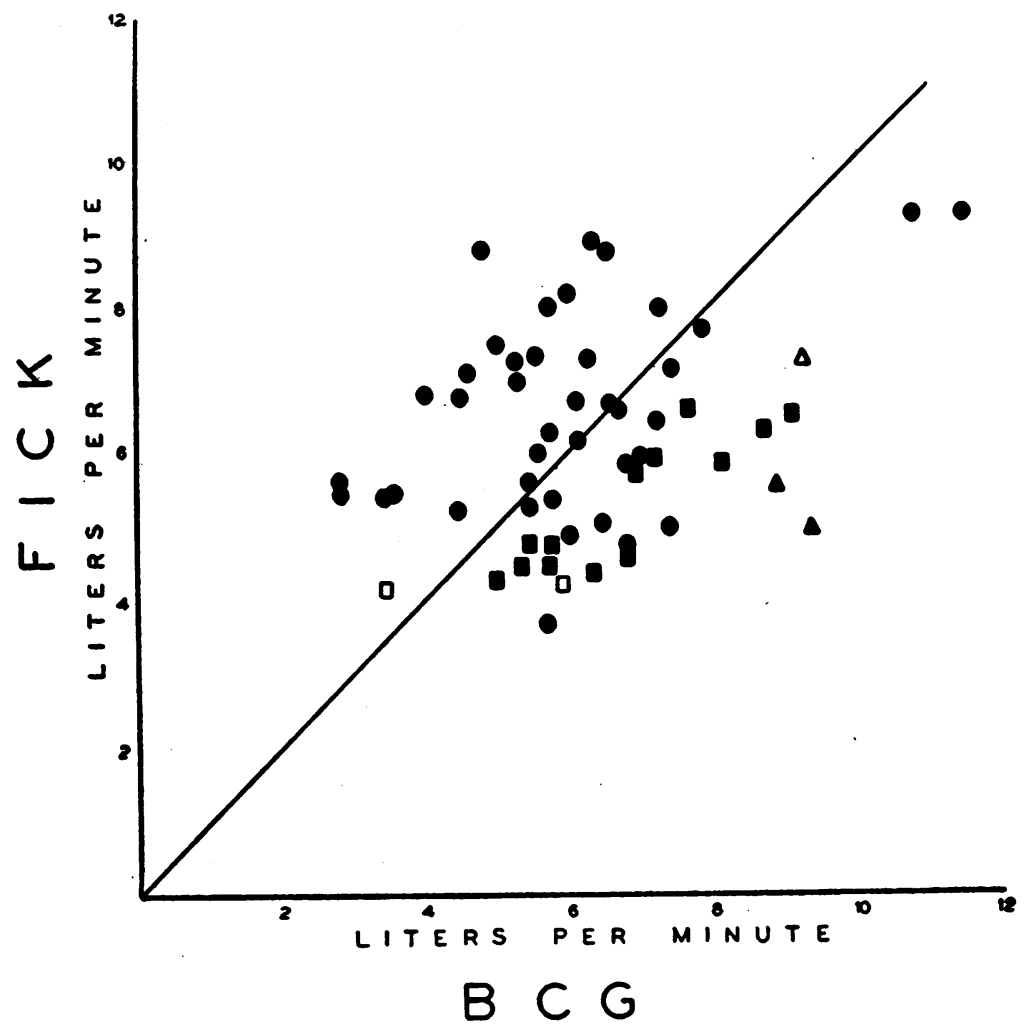

Fig. 5. The Same as Figure 4, Except That All Ballistocardogram Figures Have Been Multiplied by the Factor 1.4. See Text

\section{c. Results}

In the group of patients studied in the basal state the average cardiac output as calculated by the direct Fick procedure was 6.23 liters per minute, as compared with an average ballistocardiographic output of 4.49 liters per minute. The average cardiac index by the Fick method was 3.6; by the ballistocardiograph, 2.6. The correlation coefficient was 0.256 , the standard error \pm 0.128 , indicating no significant correlation. Figure 4 is a scatter graph of these results about the line of unity.

In Figure 5, the generally higher values of the cardiac outputs by the Fick method over those by the ballistocardiographic method have been corrected by applying to the latter an arbitrary correction factor of 1.4 , i.e. $\frac{3.6}{2.6}$ ratio. The line of unity runs through the center of the scatter. Even with this correction, however, marked discrepancies in a large proportion of instances still persist.

\section{d. Comments}

In the series reported by Nickerson, Warren, and Brannon (11), as already noted, the agreement in cardiac output between ballistocardiographic and direct Fick measurements was not very good, especially in the cases with heart disease. The normal figures were of course grouped evenly around a mean, since it was from these figures that the constants of the formula were derived. In our series, the normal subjects gave a quite different mean value of cardiac output as determined by ballistocardiogram. The scatter of our values, compared with the direct Fick measurements, was somewhat greater than those of Nickerson, Warren, and Brannon, perhaps because our patients were suffering from a wider variety and severity of cardiac, pulmonary, and other diseases, thus bringing more variable influences to bear upon the ballistic record.

It is known (6) that large differences in pulse rate will increase the error in cardiac output cal- 
TABLE II

Cardiac output data on subjects given intravenous epinephrine

\begin{tabular}{|c|c|c|c|c|c|c|c|c|}
\hline Subject & Condition of study & $\begin{array}{c}\mathrm{O}_{2} \\
\text { Cons. }\end{array}$ & $\begin{array}{c}\mathrm{O}_{2} \\
\text { Cons. }\end{array}$ & $\underset{\text { diff. }}{\mathrm{A}-\mathrm{O}}$ & $\begin{array}{l}\text { Cardiac } \\
\text { output } \\
\text { Fick }\end{array}$ & $\begin{array}{l}\text { Blood } \\
\text { pressure }\end{array}$ & $\begin{array}{c}\text { Heart } \\
\text { rate }\end{array}$ & $\begin{array}{l}\text { Cardiac } \\
\text { output } \\
\text { B.C.G. }\end{array}$ \\
\hline J. S. & $\begin{array}{l}\text { Control } \\
\text { Epinephrine i.v. } 10 \mathrm{~min} \text {. } \\
\text { Epinephrine i.v. } 20 \mathrm{~min} \text {. } \\
\text { Post epinephrine } 20 \mathrm{~min} \text {. }\end{array}$ & $\begin{array}{c}c c . / \min . \\
192 \\
218 \\
202 \\
196\end{array}$ & $\begin{array}{c}c c . / \min . / \\
\text { sq.m.B.S. } \\
114 \\
130 \\
119 \\
117\end{array}$ & $\begin{array}{c}c c . / 100 c c . \\
4.1 \\
2.7 \\
3.5 \\
4.4\end{array}$ & $\begin{array}{r}l . / \min . \\
4.68 \\
8.07 \\
5.77 \\
4.45\end{array}$ & $\begin{array}{c}m m . H g \\
92 / 64 \\
95 / 70 \\
100 / 65 \\
102 / 70\end{array}$ & $\begin{array}{l}70 \\
72 \\
74 \\
72\end{array}$ & $\begin{array}{r}\text { l. } / \text { min. } \\
4.10 \\
5.20 \\
6.40 \\
4.00\end{array}$ \\
\hline C. D. & $\begin{array}{l}\text { Control } \\
\text { Epinephrine i.v. } 10 \mathrm{~min} \text {. } \\
\text { Epinephrine i.v. } 20 \mathrm{~min} \text {. } \\
\text { Post epinephrine } 20 \mathrm{~min} .\end{array}$ & $\begin{array}{l}269 \\
272 \\
291 \\
294\end{array}$ & $\begin{array}{l}138 \\
139 \\
149 \\
151\end{array}$ & $\begin{array}{l}3.5 \\
3.5 \\
3.8 \\
3.8\end{array}$ & $\begin{array}{l}7.68 \\
7.77 \\
7.66 \\
7.74\end{array}$ & $\begin{array}{l}110 / 78 \\
118 / 82 \\
118 / 82 \\
118 / 82\end{array}$ & $\begin{array}{l}63 \\
70 \\
70 \\
62\end{array}$ & $\begin{array}{l}5.60 \\
6.48 \\
6.90 \\
4.65\end{array}$ \\
\hline T. W. & $\begin{array}{l}\text { Control } \\
\text { Epinephrine i.v. } 10 \mathrm{~min} \text {. } \\
\text { Epinephrine i.v. } 20 \mathrm{~min} \text {. } \\
\text { Post epinephrine } 20 \mathrm{~min} .\end{array}$ & $\begin{array}{l}225 \\
268 \\
321 \\
261\end{array}$ & $\begin{array}{l}130 \\
155 \\
185 \\
151\end{array}$ & $\begin{array}{l}3.5 \\
2.4 \\
2.4 \\
3.3\end{array}$ & $\begin{array}{r}6.43 \\
11.20 \\
13.40 \\
7.91\end{array}$ & $\begin{array}{l}120 / 88 \\
132 / 68 \\
138 / 68 \\
130 / 80\end{array}$ & $\begin{array}{l}80 \\
91 \\
99 \\
86\end{array}$ & $\begin{array}{l}5.15 \\
7.98 \\
7.62 \\
5.76\end{array}$ \\
\hline ז. J. & $\begin{array}{l}\text { Control } \\
\text { Epinephrine i.v. } 10 \mathrm{~min} \text {. } \\
\text { Epinephrine i.v. } 20 \mathrm{~min} \text {. } \\
\text { Post epinephrine } 20 \mathrm{~min} .\end{array}$ & $\begin{array}{l}\overline{266} \\
317 \\
285\end{array}$ & $\begin{array}{l}\overline{147} \\
175 \\
157\end{array}$ & $\begin{array}{l}- \\
1.6 \\
2.0 \\
3.2\end{array}$ & $\begin{array}{r}\overline{16.60} \\
15.85 \\
8.92\end{array}$ & $\begin{array}{l}130 / 55 \\
160 / 40 \\
160 / 40 \\
130 / 65\end{array}$ & $\begin{array}{l}76 \\
94 \\
92 \\
84\end{array}$ & $\begin{array}{r}7.35 \\
18.40 \\
17.80 \\
7.99\end{array}$ \\
\hline C. $\mathbf{M}$. & $\begin{array}{l}\text { Control } \\
\text { Epinephrine i.v. } 10 \mathrm{~min} .\end{array}$ & $\begin{array}{l}236 \\
238\end{array}$ & $\begin{array}{l}147 \\
148\end{array}$ & $\begin{array}{l}4.0 \\
2.6\end{array}$ & $\begin{array}{l}5.90 \\
9.16\end{array}$ & $\begin{array}{l}125 / 70 \\
128 / 72\end{array}$ & $\begin{array}{l}76 \\
92\end{array}$ & $\begin{array}{r}5.10 \\
10.40\end{array}$ \\
\hline
\end{tabular}

culated from the ballistocardiogram. It would seem from our data that another factor causing error, at least in the use of the Nickerson formula, may be the blood pressure. Figures 4 and 5 indicate that all cardiac outputs in hypertensive patients lie along the lower edge of the group, i.e., ballistic cardiac outputs are relatively high. Examination of the individual cases shows that this is entirely due to the factor $\mathrm{P}$ in the formula, since the ballistic complexes themselves are small.

With so poor a correlation between ballistocardiographic and direct Fick cardiac outputs, the only conclusion to be reached is that this type of ballistocardiograph does not provide a means of measuring cardiac output, in a group of patients such as those represented in this series, even though a new empirical constant is introduced in the formula.

PART III

\section{Comparison of Ballistocardiographic and Direct Fick Methods, when Cardiac Output is Altered, in the Same Subject}

There remains the question whether the ballistocardiograph can be used to indicate relative cardiac output changes in the same individual, for example as a result of drug action. An infusion of epinephrine to increase the cardiac output has been used to put this question to the test.

\section{a. Method}

A control cardiac output determination was made by each method. A slow infusion of epinephrine was then started, the rate of flow of which was adjusted so that the patient received either $0.10 \mu$ or $0.15 \mu$ per $\mathrm{Kg}$. of body weight per minute. Repeat measurements were made at 10 minutes and 20 minutes. The infusion was then terminated and an additional cardiac output determination by each method was made after a 20 -minute interval.

Five patients were so studied. It was a long and difficult procedure, and while every effort was made to establish a steady state of the circulation during the infusion, this was not completely successful in every instance. Obviously the validity of the direct Fick procedure, and to some extent of the ballistocardiographic method also, depends upon the establishment of a new "steady state" of the circulation at a different level during the time the measurements are taken.

\section{b. Results}

The results are given in Table II. A relatively steady state, so far at least as oxygen consumptions are concerned, existed in three of the five cases, J. S., C. D., and C. M.; in the other two, the oxygen consumption increased during a part of the procedure.

In one case, C. D., the cardiac output did not 
change as measured by the direct Fick method, whereas an increase was calculated on the basis of the ballistocardiogram. In the others, increases were measured by both methods; in two instances the amounts of the increase were roughly comparable; in the other two they were not.

\section{c. Comments}

It is suggested from these limited data that cardiac output changes produced by epinephrine infusion are not recorded equally or proportionately by ballistocardiograph as compared with direct Fick measurement. Further study would be needed to define these discrepancies more exactly.

\section{CONCLUSION}

The general conclusion to which this study leads is that the ballistocardiographic measurement of cardiac output gives such erratic results, with so many and such unpredictable errors from case to case, that it should no longer be used in any way whatever as an indication of this function. Earlier studies with the Starr apparatus have pointed to the same conclusion $(6,7)$. Conversely, it would seem more logical to use this instrument solely as a qualitative recording of the ballistic impulse as such, analyzing the form of the records empirically, for such correlations as can be found with clinical signs, symptoms, and prognosis $(14,15)$.

\section{SUMMARY}

1. A comparison has been made of cardiac output measured by the direct Fick (cardiac catheterization) technique, and by the use of a Nickerson critically damped ballistocardiograph, using Nickerson's formula. Sixty-four comparative determinations were made in 40 individuals, both normal subjects and patients with a variety of clinical conditions.

2. It was found that voluntary apnea or breathholding altered the ballistocardiographic record in an irregular and unpredictable manner. Ballistocardiograms were therefore taken during quiet breathing. In about 40 per cent of hospital patients, especially those with cardiac or pulmonary disease, the records were so distorted as to be unreadable, due largely to respiratory overactivity.
3. Comparison of cardiac output calculated from ballistocardiograph records and measured by the direct Fick method showed a wide scatter and poor correlation, both under basal metabolic conditions and during an intravenous infusion of epinephrine.

4. It is concluded that this type of ballistocardiograph does not provide a method of measuring cardiac output.

\section{ACKNOWLEDGMENT}

The authors are indebted to Dr. Donald Mainland of New York University for the statistical analysis of the Fick data.

\section{REFERENCES}

1a. Nickerson, J. L., and Curtis, H. J., The design of the ballistocardiograph. Am. J. Physiol., 1944, 142, 1.

b. Nickerson, J. L., The low frequency, criticallydamped ballistocardiograph. Federation Proc., 1945, 4, 201.

2. Starr, I., Rawson, A. J., Schroeder, H. A., and Joseph, N. R., Studies on the estimation of the cardiac output in man, and of the abnormalities in cardiac function, from the heart's recoil and the blood's impacts; the ballistocardiogram. Am. J. Physiol., 1939, 127, 1.

3. Starr, I., Present status of the ballistocardiograph as a means of measuring cardiac output. Federation Proc., 1945, 4, 195.

4. Cournand, A., Ranges, H. A., and Riley, R. L., Comparison of the results of the normal ballistocardiogram and a direct Fick method in measuring the cardiac output in man. J. Clin. Invest., 1942, 21, 287.

5. Hamilton, W. F., Notes on the development of the physiology of cardiac output. Federation Proc., 1945, 4, 183.

6. Cournand, A., Riley, R. L., Bradley, S. E., Breed, E. S., Noble, R. P., Lauson, H. D., Gregersen, M. I., and Richards, D. W., Studies on the circulation in clinical shock. Surgery, 1943, 13, 964.

7. Starr, I., Horwitz, O., Mayock, R. L., and Krumbhaar, E. B., Standardization of the ballistocardiogram by simulation of the heart's function at necropsy; with a clinical method for the estimation of cardiac strength and normal standards for it. Circulation, 1950, 1, 1073.

8. Barcroft, H., and Starr, I., Comparison of the actions of adrenaline and noradrenaline on the cardiac output in man. Clin. Sc., 1951, 10, 295.

9. Mathers, J. A. L., Griffeath, H. I., Levy, R. L., and Nickerson, J. L., Effect of ascending an ordinary flight of stairs on the work of the heart. Circulation, 1951, 3, 224. 
10. Paine, R. M., and Shock, N. W., The variability of cardiac output estimations made with the highfrequency undamped ballistocardiograph. Circulation, 1950, 1, 1026.

11. Nickerson, J. L., Warren, J. V., and Brannon, E. S., The cardiac output in man: studies with the low frequency, critically-damped ballistocardiograph, and the method of right atrial catheterization. J. Clin. Invest., 1947, 26, 1.

12. Starr, I., and Friedland, C. K., On the cause of the respiratory variation of the ballistocardiogram, with a note on sinus arrhythmia. J. Clin. Invest., 1946, 25, 53.

13. Seely, R. D., Nerlich, W. E., and Gregg, D. E., A comparison of cardiac output determined by the Fick procedure and a direct method using the rotameter. Circulation, 1950, 1, 1261.

14. Starr, I., On the later development of heart disease in apparently healthy persons with abnormal ballistocardiograms. Am. J. M. Sc., 1947, 214, 233.

15. Taymor, R. C., Pordy, L., Chesky, K., Moser, M., and Master, A. M., The ballistocardiogram in coronary artery disease. J.A.M.A., 1952, 148, 419.

\section{SPECIAL NOTICE TO SUBSCRIBERS}

Post Offices will no longer forward the Journal when you move.

Please notify. The Journal of Clinical Investigation, Business Office, 622 West 168th Street, New York 32, N. Y. at once when you have a change of address, and do not omit the zone number if there is one. 